ROCZNIKI NAUK PRAWNYCH

Volume XXVIII, number 4 - 2018

E n g 1 i s h v e r s i o n

DOI: http://dx.doi.org/10.18290/rnp.2018.28.4-6en

ADAM MÜLLER

\title{
CRIMINAL-LAW ASSESSMENT OF A PHYSIOTHERAPIST'S LIABILITY FOR A MEDICAL ERROR
}

\section{INTRODUCTION}

This relatively new regulation concerning the profession of physiotherapist introduced by the Act of 25 September $2015^{1}$ makes us consider the potential criminal liability of physiotherapists for their malpractice. It is important because jurisprudence has generally ignored this subject area. The literature contains a number of papers discussing criminal liability of physicians for medical errors, and in this context it should also be considered whether physiotherapists may also be similarly liable under criminal law. To this end, it is necessary, first of all, to establish what the legal nature of the profession is and whether malpractice occurs and whether such errors are medical errors.

First of all, it is worth considering what physiotherapy generally means. The word "physiotherapy" comes from the Greek words physis, which means nature and therapeia, which means treatment. ${ }^{2}$ Physiotherapy is understood as a branch of science and consists in the use of movement and other factors present in nature ${ }^{3}$ for therapeutic purposes. It is worth pointing out that the explanatory memorandum for the bill on the profession of physiotherapist

AdAm MüLLER, MA, is a graduate of studies in administration and law at Kujawy and Pomorze University in Bydgoszcz. He heads a section of the Municipal Office in Labiszyn, address: ul. Szubińska 52/18, 89-210 Łabiszyn, Poland; e-mail: muller_adam88@o2.pl; https://orcid.org/0000-0002-1949-8932.

${ }^{1}$ Act of 25 September 2015 on the profession of physiotherapist, Journal of Laws of 2015, item 1994, as amended [hereinafter referred to as APP].

${ }^{2}$ Podstawy fizjoterapii. Czesść I. Podstawy teoretyczne i wybrane aspekty praktyczne. Podręcznik dla studentów fizjoterapii i fizjoterapeutów, ed. J. Nowotny (Kraków: KASPER, 2004), 11.

${ }^{3}$ Ibid. 
says: "Physiotherapy is an integral part of medical sciences. It is a science on methods of treatment with natural means, based on various forms of physical energy existing in the human environment, such as: movement, thermal, kinetic, mechanical, electrical, light and chemical stimuli. According to the World Confederation for Physical Therapy (WCPT) definition, «physiotherapy» refers to the provision of services to individuals and populations of persons with the aim of developing, maintaining and restoring their maximum motor and functional capacity. These services can be rendered only by a physiotherapist or under his or her guidance and supervision. WCPT clearly states that a physiotherapist, within his or her competences, can examine, assess, evaluate or perform a functional diagnosis, forecast, program the procedure, as well as re-evaluate the patient for the needs of the conducted therapeutic process. Physiotherapy-as a discipline dealing with the elimination of effects or mitigation of disease processes and their consequences, their prevention and the restoration of human performance during the whole lifetime-is located within medical sciences. Due to its nature, associated with a methodically followed process of developing, maintaining and restoring the maximum mobility and functional capabilities of a person, it derives knowledge from medical sciences, physical culture and health sciences. ${ }^{4}$ The primary division of physiotherapy includes the areas of kinesiotherapy and physiotherapy. ${ }^{5}$ In addition, physiotherapy is a basic component of therapeutic (medical) rehabilitation. ${ }^{6}$ Therefore, since physiotherapy is essentially a treatment involving the performance of various types of procedures, it must be assumed that they can have an impact on human health or life. Therefore, it is not possible to exclude the liability of persons practising this profession. In the sections that follow we will only discuss a possible attribution of criminal liability to physiotherapists for their mistakes related to their profession.

\section{THE LEGAL NATURE OF THE PROFESSION OF PHYSIOTHERAPIST}

As we mentioned in the introduction, the profession of physiotherapist was regulated only by the law of 2015. Article 1 APP already indicates that

\footnotetext{
${ }^{4}$ http://orka.sejm.gov.pl/Druki7ka.nsf/0/4C6709B304CD31C3C1257DB00036B629/\%24File/ 3001.pdf [accessed May 19, 2017].

${ }^{5}$ Podstawy fizjoterapii, 11: Kinesitherapy, i.e. treatment by movement; physiotherapy, i.e. the use of physical factors other than movement, the so-called physical procedures.

${ }^{6}$ Ibid.
} 
the Act regulates, among others, the rules of the physiotherapist's profession. Article 2 APP provides that the profession of physiotherapist is an independent medical profession. It can be concluded from these first provisions of the Act that the legislator imparted a special character on the physiotherapist's profession. This also results from the explanatory memorandum for the draft act on the physiotherapist's profession, where it was stated: "National regulations give special treatment to certain professions due to their specific nature-in the case of medical professions their exceptional social nature is emphasised. Professionals in medical professions must possess unique mental, physical and moral characteristics. In addition, medical practitioners should follow an organised approach to continuously improve their professional skills. They are under a special obligation to respect the rights of the sufferer (patient) to privacy, compassion or professional confidentiality. Medical professionals (including physiotherapists) must be subject to specific professional liability."7 The introduction of the act on the physiotherapist's profession resulted also from the need to protect patients from non-professionals who often do not have even rudimentary knowledge in the field of human anatomy.

In relation to Article $4 \S 1 \mathrm{APP}$, physiotherapists are to practise their profession with due diligence, observing the principles of professional ethics, respect for patients' rights, taking care of their safety and applying recommendations of current medical knowledge. "The rules of physiotherapist's professional ethics" are currently governed by Resolution No. 20/I KZF/2016 of the First National Congress of Physiotherapists of December 29, 2016, where it is provided, among others that the physiotherapist:

- treats human health as the highest good

-follows his/her profession within the scope of their knowledge, skills and interpersonal competences

-is obliged to continuously improve their professional skills in order to provide services that are consistent with the current level of knowledge

-is obliged to perform their professional activities in conditions ensuring safe and proper provision of services. ${ }^{8}$

Patients rights should be sought primarily in the Act of 6 November 2008 on patients' rights and the Commissioner for Children's Rights, ${ }^{9}$ which, in

\footnotetext{
${ }^{7}$ http://orka.sejm.gov.pl/Druki7ka.nsf/0/4C6709B304CD31C3C1257DB00036B629/\%24File/ 3001.pdf [accessed May 19, 2017].

${ }^{8}$ https://kif.info.pl/file/2017/01/20-I-KZF-2016-zal.pdf [accessed May 19, 2017].

${ }^{9}$ Journal of Laws of 2016, item 186, as amended; see also Art. 9 APP.
} 
accordance with the titles of the relevant chapters of this Act, include rights to the following:

- health care

-information

—report adverse reactions to medicinal products

- confidentiality of information relating to them

- consent to the provision of health services

-have their intimacy and dignity respected

-review their medical records

-object to a doctor's opinion or report

-have their private and family life respected

- pastoral care

-keep deposit their valuables safely.

Of course, not all of the above-mentioned patient rights concern the profession of physiotherapist, but most of them refer directly to medical professions, including physiotherapists.

In Article $4 \S 2$ APP, the legislator indicated that physiotherapists exercise their profession by providing health services and listed a sample catalogue of such services:

- functional diagnostics of the patient

-qualification, planning and conduct of physiotherapy

-qualification, planning and implementation of kinesitherapy

-qualification, planning and performing massage

- commissioning of medical products

—selecting medical products according to the patient's needs

-teaching patients how to use medical products

-conducting preventive physiotherapeutic activity, consisting in promoting healthy behaviours and shaping and maintaining the fitness and abilities of people of different ages in order to prevent disability

-issuing opinions on the functional condition of persons subject to physiotherapy and on the course of the physiotherapeutic process

-teaching patients to use compensatory mechanisms and adapt to the changed potential of body function and activity.

Despite this sample catalogue, the array of possible physiotherapeutic procedures is quite broad, that is, actions that may affect the health or life of the patient.

Not every person can become a physiotherapist; only such a person who has specific qualifications and obtained the right to practise their profession. 
For this reason, the professional title of "physiotherapist" is subject to legal protection (Article $5 \S 2 \mathrm{APP}$ ). The requirements for granting the right to exercise the profession of physiotherapist are regulated in Chapter 3 APP. Among them, one can point to appropriate education guaranteeing theoretical preparation of a given person for this profession. ${ }^{10}$

In the context of the above, it should also be acknowledged that the profession of physiotherapist must now be classified as a profession of public confidence, because its performance involves "a certain degree of assistance to other people, usually when their various resources are threatened. At the same time, these resources are also recognised as goods by society as a whole, and their protection is recognised as the fulfilment of important social values and interests. At the same time, these are goods of significant value (even if measured subjectively) to these people."11

\section{PHYSIOTHERAPEUTIC ERROR AS A MEDICAL ERROR}

In the light of the above findings concerning mainly the fact that the act governing the physiotherapist's profession is a piece of relatively new legislation, it can be assumed that in the legal sense (if such a category can be used here) physiotherapeutic errors have not occurred earlier. This is mainly because until now it was not really clear who was a physiotherapist from the legal point of view. At present, a number of entities perform procedures under the label of physiotherapeutic procedures; however, due to appropriate restrictions in force and them having no appropriate qualifications, these individuals are not always physiotherapists in the legal sense; regardless of whether possible physiotherapeutic mistakes made both before and after the APP entered into force, in the medical sense they constituted or still constitute malpractice, even though the person did not have or does not have necessary qualifications. Therefore, our discussion of the concept of "physiotherapeutic error" should be pursued in the context of "medical errors," which jurisprudence has always dealt with quite extensively. Despite the obvious differences, the profession of physiotherapist in the legal sense has

\footnotetext{
${ }^{10}$ See also comments on the draft act on the profession of physiotherapist: http://orka.sejm. gov.pl/Druki7ka.nsf/0/4C6709B304CD31C3C1257DB00036B629/\%24File/3001.pdf [accessed May 19, 2017].

${ }^{11}$ See also P. SARNECKI, "Glosa do wyroku Sądu Najwyższego z 29 maja 2001 r., I CKN 1217/98," Palestra 5-6 (2002): 185.
} 
been equated with the profession of doctor, whose status is also regulated by law. ${ }^{12}$

We should recall that in the light of the Act the physiotherapist's profession is an independent medical profession. So, the concept of "physiotherapeutic error" should also be evaluated as such. It can therefore be assumed that "physiotherapeutic error," like "medical error," is a narrower category than that of "medical error"13 because while physiotherapeutic error can be attributed only to a physiotherapist, medical error can be attributed to any representative of the medical profession. ${ }^{14}$ Medical error is considered to constitute a lack of caution and a breach of the rules of professional conduct, which compromise goods such as human life or health. ${ }^{15}$ More precisely, medical error is defined (in relation to malpractice) by Marian Filar as "a breach of the set of rules and principles of professional conduct binding the physician performing the therapeutic procedure, which are derived from medical knowledge and practice."16 The Supreme Court argues, however, that medical error is an act (omission) of a representative of the medical profession in the field of diagnosis and therapy, inconsistent with medical science in the available extent. Negligence of the duty of care and the organization of hygiene safety and care in relation to the patient do not constitute medical error. ${ }^{17}$ Therefore, physiotherapeutic error can be assessed on the basis of the existing knowledge concerning medical errors. Medical errors can be diagnostic, therapeutic, technical or organisational. ${ }^{18}$

A diagnostic error may result from an omission to take appropriate steps to correctly diagnose or from an incorrect evaluation of the test results. An omission occurs when a physiotherapist, in order to diagnose a medical condition, does not take all available measures (diagnostic methods or means) according to the current medical knowledge. An omission also occurs if

\footnotetext{
${ }^{12}$ Act of 5 December 1996 on the professions of physician and dental surgeon, Journal of Laws of 2017, item 125, as amended.

${ }^{13}$ A. Fiutak, Prawo w medycynie (Warszawa: Wydawnictwo C.H. Beck, 2011), 77.

${ }^{14}$ See also M. WoliŃSKA, "Odpowiedzialność karna lekarza za błąd w sztuce lekarskiej," Prokuratura i Prawo 5 (2013): 23.

${ }^{15}$ See also A. LisZEwSKA, Odpowiedzialność karna za błąd w sztuce lekarskiej (Kraków: Kantor Wydawniczy Zakamycze, 1998), 28.

${ }^{16}$ M. FILAR, Lekarskie prawo karne (Kraków: Kantor Wydawniczy Zamykacze, 2000), 110.

${ }^{17}$ See also Decision of the Supreme Court of 1 April 1955, file. ref. no. IV CR 39/54, LEX no. 118379.

${ }^{18}$ FILAR, Lekarskie prawo karne, 110. The author lists the indicated medical errors as medical errors - it should be emphasized that the terms "physician's error" and "medical error" cannot be used interchangeably.
} 
a physiotherapist has not interviewed the patient. ${ }^{19}$ At the next stage of the treatment, a so-called therapeutic error may occur, which consists in the wrong choice of a treatment method or wrong implementation of treatment or inappropriate supervision of the course of treatment. ${ }^{20} \mathrm{~A}$ technical error results from technical negligence, for example, mistaking one patient for another and performing a procedure intended for another person, therefore in the strict sense of the term, this error is not a medical error. ${ }^{21}$ An organizational error, on the other hand, involves improper organization of the work of physiotherapists and other related personnel, which may cause unreliable flow of information. ${ }^{22}$

The assessment of whether a physiotherapeutic error actually occurred in a given case depends on whether the physiotherapist's action in a specific situation-given all the circumstances existing at the time and especially the data that he had or could have had at his disposal-was consistent with the requirements of current knowledge and medical science and generally accepted physiotherapeutic practice. ${ }^{23}$ Therefore, in the case where these rules of conduct are violated, we can speak of a physiotherapeutic error.

The above indicates that potential errors in physiotherapeutic practice should be classified as medical errors. Moreover, the legislator uses in Article $4 \S 2$ APP the phrase that "the pursuit of the profession of physiotherapist consists in the provision of health services," which speaks in favour of attributing such a character (i.e. of medical error) to these mistakes. This implies that physiotherapists do not provide just any services, but these are obviously health services. This in turn means that any mistakes made by physiotherapists as members of the medical profession should be classified as medical errors.

\footnotetext{
${ }^{19}$ S. RUTKOwSKI, "Wybrane zagadnienia z zakresu odpowiedzialności karnej lekarza,” Prokuratura i Prawo 9 (1999): 73-74.

${ }^{20}$ Ibid., 75.

${ }^{21}$ See also WOLIŃSKa, "Odpowiedzialność karna lekarza,” 26.

${ }^{22}$ Ibid.

${ }^{23}$ Decision of the Supreme Court of 8 September 1973, file ref. no. I KR 116/72, LEX no. 18704. The Court's reasoning refers to an error in medical art, but in the current legal and medical situation it seems that it can be applied analogously when assessing physiotherapeutic errors.
} 


\section{PHYSIOTHERAPIST'S CRIMINAL LIABILITY FOR A MEDICAL ERROR}

Since a mistake made in the area of physiotherapy is in fact a medical error, we should wonder whether in this context physiotherapists can be held criminally responsible. The act on the profession of physiotherapist provides for penal regulations, but none of them applies to liability for medical errors. ${ }^{24}$ Therefore, such liability should be sought in the Penal Code ${ }^{25}$ Chapter 19 entitled "Offences Against Life and Health." Due to the fact that the provision of physiotherapeutic services is associated with the performance of treatments involving various types of manipulation (manual therapy) or the use of tools (using electricity or heat), where in both cases contact with the human body occurs, such goods as health or life may be compromised. In the first case (manipulation), a physiotherapist's error may consist in a technically incorrect procedure, and in the second case in an incorrect setting of instrument parameters.

The sources of physiotherapists' criminal liability for medical errors are to be found primarily at the level of the perpetrator's fault. Filar points out that the criminal liability of a medical worker occurs when fault and medical error coincide, that is, an act contrary to medical knowledge and practice occurs resulting in a negative outcome in the form of violation or exposure to direct danger of a legal good. ${ }^{26}$ In addition, in order to attribute criminal liability, it is necessary to establish a causal link between the physiotherapist's actions and the outcome concerning the life or health of the patient. Therefore, the relationship between the error and the health effect (health deterioration or death) should be assessed.

The fault of a physiotherapist results primarily from a faulty decisionmaking process based on insufficient medical knowledge in a given area or insufficient diligence under particular circumstances. In such a situation, the physiotherapist should be aware of the fact that he or she may make a mistake and bring about negative consequences. ${ }^{27}$

\footnotetext{
${ }^{24}$ The penal provisions contained in the Act on the profession of physiotherapist provide only (generally speaking) for liability for practising without the necessary qualifications.

${ }^{25}$ Act of 6 June 1997-the Penal Code, Journal of Laws 2016, item 1137 as amended. [hereinafter referred to as $\mathrm{PC}$ ].

${ }^{26}$ M. FILAR, "Odpowiedzialność karna lekarza za zaniechanie udzielenia świadczenia zdrowotnego (nieudzielenie pomocy)," Prawo i Medycyna 1 (1999), 71.

${ }^{27}$ See also R. Szostak and M. KozaK, "Odpowiedzialność karna lekarzy za błędy medyczne," Studia Prawnoustrojowe 23 (2014), 126.
} 
We cannot rule out situations where physiotherapists will be held liable for an intentional injury or death, but generally we should assume that physiotherapists' liability for medical errors can result from unintentional perpetration of a prohibited act due to failure to observe caution required in given circumstances. ${ }^{28}$ It is assumed that precautionary principles outline the limits of socially acceptable risk, indicating which behaviours are advisable and which are not in relation to a particular good in order to minimise the risk of its exposure or infringement, thereby specifying the extent of permitted risky behaviours. ${ }^{29}$

In addition to the above, it is worth pointing out that an assessment whether a physiotherapist is actually criminally liable should be made primarily on the basis of Article 1 PC. This provision lays down conditions of liability. Firstly, an offence must be threatened with a statutory penalty applicable at the time it is committed. Secondly, the social harm caused by this offence must be greater than negligible. Thirdly, the offence must be culpable. In this context, the physiotherapist's responsibility for a medical error is first of all assessed in respect of the degree of social harm and the degree of guilt. Pursuant to Article $115 \S 2$ PC, when assessing the degree of social harmfulness of an offence, the court takes into account the type and nature of the infringed interest, the size of the damage caused or threatened, the manner and circumstances of the act, the seriousness of the breached duties, as well as the form of the intention, the perpetrator's motivation, the type of infringed precautionary rules and the degree of the breach. It should be emphasized that in the case of consequences resulting from medical errors consisting in health impairment or death of a patient, we will always deal with a higher than negligible degree of social harm. However, the degree of guilt, or even exclusion of guilt, will primarily depend on specific circumstances. We will speak of a completely different degree of guilt in a situation where a physiotherapist makes an incorrect diagnosis and proceeds to the next stage of treatment (also incorrectly), in contrast to a situation where a physiotherapist-on the basis of reliable medical records of the patientperforms a procedure detrimental to the latter's health or life, ordered by a doctor or another physiotherapist.

With regard to the above, physiotherapists may certainly be liable under Article $156 \S 1$ point 2 PC, which states that a person who causes serious health impairment in the form of another severe disability (other than that

\footnotetext{
${ }^{28}$ LISZEWSKA, Odpowiedzialność karna, 28.

${ }^{29}$ W. WróBel and A. Zoll, Polskie prawo karne (Kraków: Znak 2014, 174).
} 
indicated in Art. $156 \S 1$ point 1), a serious incurable or long-term disease, life threatening disease, persistent mental illness, total or significant permanent inability to work in an occupation, or a permanent, significant disfigurement or deformation of the body, shall be subject to imprisonment for a term of between 1 and 10 years (the basic type). If the perpetrator acted unintentionally, the penalty shall be up to 3 years of imprisonment (Art. 156 $\S 2$ - the privileged type), and if death of a human being is a consequence of his or her offence, then the penalty shall be from 2 to 12 years of imprisonment (Art. $156 \S 3$-the qualified type). Article 156 of the Penal Code focuses on the protection of a person against real damage to his or her health, and further protects his or her life against further consequences in the form of death. ${ }^{30}$ The offence of severe health impairment is a general one and may be committed in the basic type-intentionally (both direct and possible), in the privileged type-unintentionally (generally regarding physiotherapists due to negative effects on health or life resulting from a medical error) and in the qualified type-intentionally and unintentionally. ${ }^{31}$ The perpetrator's act need not be the only cause of death of the victim to be classified as a qualified crime. It is sufficient to establish a causal link between this action and at least one of the causes of the outcome. ${ }^{32}$ In the case an offence under Article $156 \mathrm{PC}$, the court can, in addition to penalising the physiotherapist, order a criminal measure in the form of a ban on him or her practising the profession. ${ }^{33}$

If physiotherapists may be responsible for a medical error under Article 156 of the Penal Code, all the more so they may be liable under Article 157 PC (argumentum a maiori ad minus). The provision of Article 157 provides for criminal liability for the so-called moderate and minor health impairment. Article $157 \S 1$ provides that any person who causes an impairment of bodily functions or disturbance to health, other than the one specified in Article $156 \S 1$ shall be subject to the penalty of imprisonment of up to 5 years. This is enough to conclude that, as in Article 156, the thing protected is human health, and the difference boils down only to the degree of violation of

\footnotetext{
${ }^{30}$ Kodeks karny. Komentarz, ed. V. Konarska-Wrzosek, LEX/el. 2017, the commentary on Art. 156.

${ }^{31}$ Kodeks karny. Komentarz, ed. M. Mozgawa, 7th ed., LEX/el. 2017, the commentary on Art. 156.

${ }^{32}$ See also, among others, Judgement of the Court of Appeal in Lublin of 20 October 2009, file ref. no. II Aka 97/09, LEX no. 550507.

${ }^{33}$ Kodeks karny. Komentarz, ed. M. Mozgawa, the commentary on Art. 156.
} 
this interest. ${ }^{34}$ In the case of a minor impairment of bodily activity or disturbance of health, that is one lasting no longer than 7 days, the perpetrator is liable to a fine, restriction of liberty or imprisonment for up to 2 years (Article $157 \S 2$ ). Both these types (under $\S \S 1$ and 2) can be committed intentionally with a direct or possible intent. ${ }^{35}$ However, the provision of Article $157 \S 3$ provides for the privileged type of acts specified in $\S 1$ or 2 if the perpetrator acted unintentionally (generally in the case of physiotherapists due to negative consequences for health or life resulting from a medical error). In such a situation, the legislator provides for the penalty of a fine, the penalty of restriction of liberty or the penalty of imprisonment for up to one year. The offence under Article 157 PC is common. Due to the unique nature of medical services provided by physiotherapists since they often work upon a medical order and the potential of severe health impairment is lower (compare Art. 6 APP), it seems, then, that they will incur criminal liability much more frequently under Article 157 PC than Article 156 PC.

Notwithstanding the above, the penal liability of physiotherapists for consequences resulting from medical error may be sought under Article 160 $\S 1$ PC, which states that anyone who exposes a person to direct danger of loss of life or serious injury to health shall be subject to the penalty of imprisonment for up to 3 years. The misdemeanour provided for in this provision protects health and life. It is a common crime. ${ }^{36}$ At this point, it is that in Article 4 para. 1 APP the legislator imposed on physiotherapists the obligation to ensure safety of their patients. In this context, it should be determined whether or not the physiotherapist will incur liability under Article $160 \S 2$ PC, which states that if the perpetrator is obliged to take care of a person at risk, he or she is subject to imprisonment for a period between 3 months and 5 years. This is an individual, improper offence because only a guarantor can commit it. ${ }^{37}$ Assuming that the physiotherapist is legally obliged to take care of the patient pursuant to the APP, then in the event of the patient's exposure to the risk of loss of life or serious damage to their health-which may result from medical error (e.g. incorrect diagnosis or therapy) - he or she will be liable for the qualified type offence. At the same time, this liability must be assessed within the scope of obligations incumbent on the guarantor (Art. $160 \S 2$ PC), which must be defined for the

\footnotetext{
${ }^{34}$ Kodeks karny. Część szczególna. Volume II. Komentarz do art. 117-277 k.k., ed. A. Zoll, 4th ed., LEX/el. 2017, the commentary on Art. 157.

${ }^{35}$ Kodeks karny. Komentarz, ed. M. Mozgawa, the commentary on Art. 157.

${ }^{36}$ Ibid., the commentary on Art. 160.

${ }^{37}$ Ibid.
} 
moment at which the guarantor operates and using the information available to them concerning the facts of the case. Conclusions should be drawn in relation to that moment as to the extent to which those obligations must be realised and in relation to the dangers which may arise from their omissions. ${ }^{38}$ A crime may be committed intentionally or unintentionally under the conditions specified in Article $160 \S 1$ or $\S 2$ PC, but in the latter case the perpetrator shall be subject to a fine, restriction of liberty or imprisonment for a term up to one year (Art. $160 \S 3$ PC). A physiotherapist will not incur liability, however, if he or she has voluntarily avert a danger (Article 160 § 4 PC).

\section{CONCLUSION}

The presented analysis shows that errors occurring in the course of physiotherapy are medical errors for which physiotherapists may be held criminally responsible. This liability will, in principle, result from a criminal act committed unintentionally, since physiotherapists' role is to improve the patient's health, and therefore rather unlikely that they should wish to act otherwise. Therefore, the satisfaction of the statutory requirements for a prohibited act may occur as a result of a failure to observe the precautions required under particular circumstances (Art. $9 \S 2$ PC), in particular as a result of a physiotherapeutic error. For such a proposition, it is important that the legislator has finally decided to regulate the status of the physiotherapist's profession. In these circumstances, the term "physiotherapeutic error" should be interpreted in its strict sense because an individual who does not have the right to conduct physiotherapy cannot provide such services and, legally, such errors cannot be attributed to them. At the same time, it is not determined whether the term can be used in the medical context also to refer to persons providing physiotherapeutic services even if formally they are not physiotherapists. At any rate, such individuals will be criminally liable under Articles 136-140 APP, which in turn does not exclude the possibility to hold them liable under Articles 156, 157 or 160 PC. Professional physiotherapists, as previously indicated, may certainly be held responsible for the consequences of medical errors pursuant to Articles 156, 157 or 160 PC.

\footnotetext{
${ }^{38}$ Decision of the Supreme Court of 19 January 2011, file ref. no. IV KK 356/10, LEX no. 730270
} 


\title{
BIBLIOGRAPHY
}

\author{
SOURCES OF LAW
}

Ustawa z dnia 25 września 2015 r. o zawodzie fizjoterapeuty [Act of 25 September 2015 on the profession of physiotherapist]. Journal of Laws of 2015, item1994, as amended.

Ustawa z dnia 5 grudnia 1996 r. o zawodach lekarza i lekarza dentysty [Act of 5 December 1996 on the professions of physician and dental surgeon]. Journal of Laws of 2017, No. 28, item 125 , as amended.

Ustawa z dnia 6 czerwca 1997 r. Kodeks karny [Act of 6 June 1997-the Penal Code]. Journal of Laws of 2016, item 1137, as amended.

Ustawa z dnia 6 listopada 2008 r. o prawach pacjenta i Rzeczniku Praw Pacjenta [Act of 6 November 2008 on the patient's rights and the Commissioner for Children's Rights]. Journal of Laws of 2016, item 186, as amended.

\section{CASE LAW}

Decision of the Supreme Court of 1 April 1955, file ref. no. IV CR 39/54. LEX no. 118379.

Order of the Supreme Court of 19 January 2011, file ref. no. IV KK 356/10. LEX no. 730270.

Judgement of the Court of Appeal in Lublin of 20 October 2009, file ref. no. II Aka 97/09. LEX no. 550507.

Judgement of the Supreme Court of 8 September 1973, file ref. no. I KR 116/72. LEX no. 18704.

\section{LITERATURE}

FILAR, Marian. Lekarskie prawo karne. Kraków: Kantor Wydawniczy Zakamycze, 2000.

FILAR, Marian. "Odpowiedzialność karna lekarza za zaniechanie udzielenia świadczenia zdrowotnego (nieudzielenie pomocy)." Prawo i Medycyna 1 (1999): 71.

FiutaK, Agnieszka. Prawo w medycynie. Warszawa: Wydawnictwo C.H. Beck, 2011.

Kodeks karny. Czesść szczególna. Tom II. Komentarz do art. 117-277 k.k., edited by Andrzej Zoll. 4th ed. LEX/el. 2017.

Kodeks karny. Komentarz, edited by Marek Mozgawa. 7th ed. LEX/el. 2017.

Kodeks karny. Komentarz, edited by Violetta Konarska-Wrzosek. LEX/el. 2017.

LisZEwSKA, Agnieszka. Odpowiedzialność karna za błąd w sztuce lekarskiej. Kraków: Kantor Wydawniczy Zakamycze, 1998.

Podstawy fizjoterapii. Część I. Podstawy teoretyczne i wybrane aspekty praktyczne. Podręcznik dla studentów fizjoterapii i fizjoterapeutów, edited by Janusz Nowotny. Kraków: KASPER, 2004.

RuTKOwSKI, Stanisław. "Wybrane zagadnienia z zakresu odpowiedzialności karnej lekarza." Prokuratura i Prawo 9 (1999): 71-91.

SARNECKI, Paweł. "Glosa do wyroku Sądu Najwyższego z 29 maja 2001 r., I CKN 1217/98." Palestra 5-6 (2002): 185-88.

Szostak, Robert, and Magdalena KozAK. "Odpowiedzialność karna lekarzy za błędy medyczne.” Studia Prawnoustrojowe 23 (2014): 119-30.

WolIŃSKA, Magdalena. “Odpowiedzialność karna lekarza za błąd w sztuce lekarskiej.” Prokuratura i Prawo 5 (2013): 19-35.

WróBEL, Włodzimierz, and Andrzej ZoLl. Polskie prawo karne. Kraków: Znak, 2014. 


\title{
CRIMINAL-LAW ASSESSMENT OF A PHYSIOTHERAPIST'S LIABILITY FOR A MEDICAL ERROR
}

\begin{abstract}
Summary
The article presents a legal assessment of physiotherapeutic errors. It was not unimportant for this assessment that the regulation of the physiotherapist's profession was proven, which made it possible to confirm that errors in physiotherapeutic art are in fact medical errors. In turn this allowed us to consider the possible criminal liability of this occupational group for medical errors. Final conclusions have finally confirmed that physiotherapists can be held liable for medical errors under Articles 156, 157 or 160 PC.
\end{abstract}

Keywords: physiotherapy; law; liability.

\section{Translated by Tomasz Patkowski}

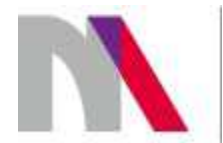

The preparation of the English version of Roczniki Nauk Prawnych (Annals of Iuridical Sciences) and its publication in electronic databases was financed under contract no. 836/PDUN/2018 from the resources of the Minister of Science and Higher Education for the popularization of science. 